International Research Journal of Engineering, IT \& Scientific Research
Available online at https://sloap.org/journals/index.php/irjeis/
Vol. 4 No. 5, September 2018, pages: $7 \sim 16$
ISSN: 2454-2261
https://sloap.org/journals/index.php/irjeis/article/view/285

\title{
Development of Three Tier Static Electricity Diagnostic Test to Identify Student Conceptions about Static Electricity
}

\author{
Ni Made Dwita Pradnya Suantari a \\ Ketut Suma $^{\text {b }}$ \\ Ni Made Pujani ${ }^{c}$
}

Article history:

Received: 15 May 2018

Accepted: 30 August 2018

Published: 7 September 2018

\section{Keywords:}

Difficulty Index;

Discrimination Index;

Internal Consistency Index;

Reliability Index:

Validity;

\begin{abstract}
The purpose of this research was to develop and validate Three Tier Static Electricity Diagnostic Test (TTSEDT). The development procedure consists of four stages: define, design, develop, and validation. The subjects of this study consist of 2 physics education experts and 120 high school students, in 12th grade. The response of two experts was used to determine the content validity of TTSEDT. Meanwhile, the students' responses were used to determine the items internal consistency, discrimination index, difficulty index, and reliability index. The reliability of TTSDET was determined by KR-20. The results showed that: (1) TTSEDT meet content validity which means that TTSEDT items are really measures the students' conceptions and misconceptions about static electricity; (2) the items internal consistency index is in the interval $0.20-0.47$; (3) the items discrimination index is higher than 0.20 ; (4) the difficulty index of test items is in the interval of $0.25-0.75$; (5) the reliability index of TTSEDT is $0.73(\mathrm{p}<0.05)$. TTSEDT is a valid, reliable, and effective instrument for identifying students' conceptions of static electricity.
\end{abstract}

2454-2261 ${ }^{\circledR}$ Copyright 2018. The Author. This is an open-access article under the CC BY-SA license (https://creativecommons.org/licenses/by-sa/4.0/) All rights reserved.

\section{Author correspondence: \\ Ketut Suma, \\ Physics Education Department \\ Ganesha University of Education, Bali, Indonesia \\ Email address: sumakt1959@gmail.com}

\section{Introduction}

Studies (Gonen \& Kopckay: 2010; Dud, et al.:2015; Blas, Seidel, \& Fernandez: 2010) show that before learning science in a class, learners have had a conception that most inconsistent with the scientific concept. Student conceptions that are inconsistent to the scientific concepts are given various labels such as preconceptions (Turgut \& Turgut: 2011), Children science (Bell: 1993; Osborne, et al.: 1985); alternative conceptions (Peterson: 2002),

${ }^{a}$ Graduate of the Master of Science Education Program, Ganesha University of Education, Bali, Indonesia

${ }^{\mathrm{b}}$ Physics Education Department, Ganesha University of Education, Bali, Indonesia

${ }^{c}$ Ganesha University of Education, Sing raja, Bali, Indonesia 
conception naïve (Alwan: 2010), and misconception (Brown \& Clement: 1989; Onder: 2017). It has been widely accepted that misconceptions are stable, difficult to change (Sencar \& Eryilmaz: 2004; Kaltakci \& Didis: 2007), and contribute negatively to learning (Blas, Seidel, \& Fernandez: 2010; Ozkan \& Selcuk: 2012). Therefore, the identification of student misconceptions becomes essential for the effective teaching of physics. Misconceptions can be detected by testing students. This test can be done at the beginning or the end of the lesson. To reveal the existence of misconception then required a type of test that is able to analyze students' difficulties and weaknesses. The type of test is a diagnostic test. The Diagnostic test is a test used to know the weaknesses of students so that the weaknesses can be given appropriate treatment (Arikunto: 2009). Diagnostic tests are useful for learning difficulties encountered by students, including misconceptions. By knowing the students' misconception, the teacher can immediately find a solution to solve the problem. Through diagnostic tests can be known about concepts that have been understood and that have not been understood by students.

In physics education, student misconceptions have been measured in various ways such as interviews (Osborne \& Gilbert: 197; Osborne \& Gilbert: 1980; Eshach: 2003), open questions (Palacious, Cazorla, and Cervantes, in Gurel, Eryimaz, \& McDermott: 2015; Colin, Chauvet \& Viennot: 2002; Taslidere: 2016), and ordinary multiple choice test (Treagust: 1998; Cataloglu \& Robinett: 2002; Engelhardt \& Beichner: 2004; Maloney, et al.:2001; Libarkin: 2008; Bardar, et al.: 2007). Interviews were conducted with the aim of discovering what students think and how they feel about something. Interview techniques are a flexible technique and allow for more in-depth student information. However, this technique requires the training of the interviewer, it takes a long time for a large number of subjects if it is to obtain broader generalize, the interviewer may contaminate the findings of the researcher (Gurel, Eryimaz, \& McDermott: 2015).

Ordinary multiple choice test is one alternative that is used to overcome difficulties encountered in the interview process and open test. This multiple-choice test can be directly assessed and applied to a large number of students. The development of multiple-choice tests on students' misconceptions has the potential to make a valuable contribution to the body of work in the area of misconceptions and to assist in the process of helping science teachers to more readily use the findings of research in their classrooms (Treagust: 1998). From a usage point of view, multiple-choice tests are valid and reliable, easy to calculate, manageable, allowing teachers to effectively assess students' understanding (Gurel, Eryimaz, \& McDermott: 2015).

Like interview techniques and open questions, ordinary multiple choice tests are also not spared from the weaknesses. Some of the disadvantages of an ordinary multiple-choice test include: (1) student's guess contributes to error variance and reduces test reliability, (2) selected choice does not provide in-depth insights about student ideas or conceptual understanding, (3) students are forced to choose each answer from a very limited list of choices, which prevents them from building, organizing and presenting their own answers, (4) It is very difficult to write a good multiple-choice question. In addition to the above deficiencies, the ordinary multiple-choice test cannot demonstrate students' deep understanding of the correct answers (Chang, Yeh, \& Barufaldi : 2010). In other words, the ordinary multiple-choice test cannot distinguish whether the student's correct answer is supported by correct reasoning or improper reasoning (Bento: 2018).

Referring to the weaknesses of the ordinary multiple choice test, researchers like Treagust (1998), Chandrasegaran, et al. (2007), Bilal \& Erol (2009), and Kilic \& Saglam (2009) developing the two-tier test. In general, two-tier tests are a diagnostic instrument in which the first tier contains questions with alternative answers such as the ordinary multiple choice test, and the second tier contains the choice of reason for the answer of the first tier. This two-tier diagnostic test allows researchers to identify students' wrong answers caused by misconception, and whether the true answer is caused by a scientific understanding (Taslidere: 2016). Two-tier tests are more efficient than ordinary multiple choice tests, although these tests have some disadvantages in distinguishing the lack of knowledge from misconceptions, mistakes, or scientific knowledge (Gurel, Eryimaz, \& McDermott: 2015). This happens because there was always a chance for students to guess the answers. Thus, the students' correct answers may come from a scientific understanding or guess, as well as a student's wrong answer may be due to a lack of knowledge or misconception (Taslidere: 2016)

Departing from the limitations of two-tier diagnostic tests, the researchers developed a three-tier diagnostic test by adding a third tier to each test item that asked students' beliefs about the answers given to the first and second tiers. In a three-tier diagnostic test, the researcher constructs a multiple-choice test in which the first tier is an ordinary multiple choice test, the second tier is a multiple choice test that asks the reasoning of the first student's answer, and the third tier asks students' level of confidence in the first and second tier answers (Gurel, Eryimaz, \& McDermott: 2015). In the field of physics teaching the development of three-tier diagnostic test has been done on various topics such as : geometric optic (Kutluay: 2005); force and motion (Turker: 2005); gravity concepts 
(Kaltakci \& Didis: 2007); the nature and propagation of some common wave phenomena (Caleon \& Subramaniam: 2008), waves (Caleon \& Subramaniam: 2010), simple electric circuit (Pesman \& Eryilmaz: 2010), momentum and collision (Pacala: 2018). This research is focused on developing the three-tier diagnostic test for static electricity called Three Tier Static Electricity Diagnostic Test (TTSEDT). This research is conducted to answer the problems as follows.

a) How is the content validity of TTSEDT?

b) How are the items internal consistency of TTSEDT?

c) How are the items discrimination Index of TTSEDT?

d) How is the reliability of TTSEDT?

e) Is the TTSEDT effective to identify students' conception about static electricity?

\section{Materials and Methods}

The development of TTSEDT consists of four stages: Define, Design, and Develop, and Validation (modified from (Thiagarajan: 1974).

\section{Define}

This stage defines the TTSEDT needs related to the conception and misconceptions that occur in static electricity. Scientific concepts are identified from the Basic Competencies of High School Curriculum. Meanwhile, various misconceptions on static electricity are identified from the various literature and research results using ordinary multiple choice tests and two-tier multiple-choice tests such as (Maloney, et al.:2001; Bilal \& Erol: 2009; Koudelkova \& Dvorak: 2014).

\section{Design}

This stage begins with the preparation of a test grid to ensure compatibility between test items and the concepts to be measured. The first tier of TTSEDT is designed in multiple-choice form with four alternative choices. The alternative correct answer is a scientific concept, while alternative wrong answers are misconceptions related to certain concepts. The second tier of TTSEDT is designed in multiple-choice form, with alternative answers in the form of reasons for alternative answers in the first tier. An alternative reason for the correct answer in the second tier is the scientific explanation of the concept, while the alternative wrong answer is a non-scientific explanation. The third tier of TTSEDT is designed in the form of a choice of confidence in the answers in the first and second tiers which are avoided by two alternatives, namely sure and not sure.

\section{Develop}

Developed the Three-Tier Multiple Choice Test items in accordance with the identified concepts of the high school curriculum, findings with ordinary multiple choice tests and two-tier tests. Some items are developed from an ordinary multiple choice test from (Maloney, et al.: 2001; Bilal \& Erol: 2009; Koudelkova \& Dvorak: 2014), and partly developed by the author himself.

\section{Validation}

The content validity of the TTSEDT is obtained by analyzing whether the test items really measure key concepts and misconceptions of students about static electricity. Content validation was carried out by two physics education experts. These experts are asked to analyze the items that include item statements, alternative choices, answer keys, and distracted. In the first tier, the experts analyze whether the item statement is easy to understand? Is the answer key a scientific concept? Is the distracters are the variety of students' misconceptions about certain concepts. In the second tier, experts are asked to analyze whether the answer key for student reasons is a scientific explanation and whether distracter is a non-scientific explanation of the concepts asked in the first tier. They made some corrections, comments, and suggestion on some of the items that were used to revise the item. At this stage, pilot testing was performed for internal consistency analysis, discrimination index, difficulty index, and test reliability. Pilot testing

Suantari, N. M. D. P., Suma, K., \& Pujani, N. M. (2018). Development of three tier static electricity diagnostic test to identify student conceptions about static electricity. International Research Journal of Engineering, IT \& Scientific Research, 4(5), 7-16. https://doi.org/10.21744/irjeis.v4n5.285 
was conducted in SMA Negeri 1 Kediri in the odd semester of the academic year 2017/2018. The number of students participating in this pilot testing is 102 people. The study begins in October to November 2017.

\section{Data Analysis}

Data analysis was carried out in a descriptive quantitative and qualitative manner. The content validity is expressed qualitatively based on the expert responses. Calculation of internal consistency index, discrimination index, difficulty index, and reliability of the test is assisted by SPSS for Window. Internal consistency index, discrimination index, difficulty index, and reliability were determined from the third tier score. In the third tier score of 1 is given if the student's answer in the first tier is right, the reason in the second tier is right and the third tier answer is "sure". The score of 0 is given for the other answers. Reliability index is calculated by KR-20 formula (Arikunto: 2009). Variety of students 'conceptions are categorized into the scientific concept, lack of confidence, misconception, and lack of knowledge based on a combination of students' answers in the first, second and third tiers with criteria as in Table 1.

Table 1

Categories of student knowledge on each test item

\begin{tabular}{llll}
\hline $1^{\text {st }}$ tier response & $2^{\text {nd }}$ tier response & $3^{\text {rd }}$ tier response & Category of students conception \\
\hline True & True & Sure & Scientific Concept \\
Correct & Correct & not sure & Lack of Confidence \\
Corect & Incorrect & Sure & Misconception \\
Incortect & Correct & Sure & Misconception \\
Incorrect & Incorrect & Sure & Misconception \\
Incorrect & Correct & Not sure & Lack of Knowledge \\
Correct & Incorrect & Not sure & Lack of knowledge \\
Incorrect & Incorrect & Not sure & Lack of Knowledge \\
\hline
\end{tabular}

Adapted from Arslan, Cigdemoglu, \& Mosely (2013).

\section{Results and Discussions}

\subsection{Content Validity}

According to experts, the TTSEDT developed meet content validity. This means that TTSEDT items are really measuring the students' conceptions and misconceptions about static electricity. In the first tier, the answer keys are scientific concepts and the distracters are the non-scientific concepts. In the second tier, answer keys are the scientific explanations of the concept and the distracters are the nonscientific explanation. In this study, the test material includes concepts of charge, electrostatic force, electric field, potential energy, electrical potential, and capacitors. This material was derived from the $12^{\text {th }}$-grade high school curriculum.

\subsection{Items Internal Validity}

Of the 30 items tested, there are 29 items that have an internal validity index in the range of 0.20-0.49 as shown in table 3. These values are greater than the table values $\left(\mathrm{r}_{\mathrm{table}}=0.195\right)$ at the $5 \%$ significance level. This means that TTSDET items are consistent with the entire item.

Table 2

Items internal validity index

\begin{tabular}{cccc}
\hline Items number & Internal validity $(\mathrm{r})$ & Items number & Internal validity $(\mathrm{r})$ \\
\hline 1 & 0.39 & 16 & 0.45 \\
2 & 0.42 & 17 & 0.28 \\
3 & 0.34 & 18 & 0.45 \\
\hline
\end{tabular}




\begin{tabular}{cccc}
\hline 4 & 0.43 & 19 & 0.34 \\
5 & 0.38 & 20 & 0.32 \\
6 & 0.25 & 21 & 0.20 \\
7 & 0.34 & 22 & 0.35 \\
8 & 0.36 & 23 & 0.36 \\
9 & 0.23 & 24 & 0.47 \\
10 & 0.47 & 25 & 0.28 \\
11 & 0.35 & 26 & 0.29 \\
12 & 0.31 & 27 & 0.30 \\
13 & 0.21 & 28 & 0.24 \\
14 & 0.33 & 29 & 0.39 \\
\hline
\end{tabular}

Note: $r_{\text {table }}=0.195$

\subsection{Items Discrimination Index}

Table 3 shows a summary of the results of items discrimination index analysis of TTSEDT. There are 21 items $(72,4 \%)$ which have discrimination index in the medium category, 7 items $(24,1 \%)$ have discrimination index in the good category, and 1 item (3.4\%) has a discrimination index in the very good category. Al of the 29 test items have a discrimination higher than 0.20 , which means it qualifies as a good test. Discrimination is defined as the ability of a items to distinguish between high-ability students and low-ability students (Arikunto: 2009). That is, if the test is given to students who are clever will be more likely to be answered correctly, whereas if given to learners who have the low ability will be the more wrong answer.

Table 3

Items discrimination index of TTSEDT

\begin{tabular}{cclccl}
\hline $\begin{array}{c}\text { Item } \\
\text { number }\end{array}$ & $\begin{array}{c}\text { Discrimination } \\
\text { Index (D) }\end{array}$ & Criteria & $\begin{array}{c}\text { Item } \\
\text { number }\end{array}$ & $\begin{array}{c}\text { Discrimination } \\
\text { index (D) }\end{array}$ & Criteria \\
\hline 1 & 0,39 & Medium & 16 & 0,44 & Good \\
2 & 0,42 & Good & 17 & 0,28 & Medium \\
3 & 0,34 & Medium & 18 & 0,45 & Good \\
4 & 0,43 & Good & 19 & 0,34 & Medium \\
5 & 0,38 & Medium & 20 & 0,32 & Medium \\
6 & 0,24 & Medium & 21 & 0,21 & Medium \\
7 & 0,34 & Medium & 22 & 0,35 & Medium \\
8 & 0,36 & Medium & 23 & 0,36 & Medium \\
9 & 0,25 & Good & 24 & 0,47 & Good \\
10 & 0,47 & Good & 25 & 0,28 & Medium \\
11 & 0,34 & Medium & 26 & 0,29 & Medium \\
12 & 0,30 & Medium & 27 & 0,30 & Medium \\
13 & 0,21 & Medium & 28 & 0,24 & Medium \\
14 & 0,33 & Medium & 29 & 1,00 & Very Good \\
15 & 0,31 & Medium & & & \\
\hline
\end{tabular}

There are 21 items $(72,4 \%)$ which have discrimination index in the medium category, 7 items $(24,1 \%)$ have discrimination index in the good category, and 1 item (3.4\%) has a discrimination index in the very good category. $\mathrm{Al}$ of the 29 test items has a discrimination higher than 0.20 , which means it qualifies as a good test. Discrimination is defined as the ability of items to distinguish between high-ability students and low-ability students (Arikunto: 2009). That is, if the test is given to students who are clever will be more likely to be answered correctly, whereas if given to learners who have the low ability will be the more wrong answer.

Suantari, N. M. D. P., Suma, K., \& Pujani, N. M. (2018). Development of three tier static electricity diagnostic test to identify student conceptions about static electricity. International Research Journal of Engineering, IT \& Scientific Research, 4(5), 7-16. https://doi.org/10.21744/irjeis.v4n5.285 


\subsection{Items Difficulty Index}

The results of the difficulty index analysis of TTSEDT items are presented in Table 4.

Table 4

Results of the third level diagnostic test assessment

\begin{tabular}{cccccc}
\hline $\begin{array}{c}\text { Item } \\
\text { number }\end{array}$ & $\begin{array}{c}\text { Difficulty } \\
\text { Index }\end{array}$ & Criteria & $\begin{array}{c}\text { Item } \\
\text { number }\end{array}$ & $\begin{array}{c}\text { Difficulty } \\
\text { index }\end{array}$ & Criteria \\
\hline 1 & 0,51 & Medium & 16 & 0,48 & Medium \\
2 & 0,44 & Medium & 17 & 0,39 & Medium \\
3 & 0,50 & Medium & 18 & 0,40 & Medium \\
4 & 0,53 & Medium & 19 & 0,44 & Medium \\
5 & 0,46 & Medium & 20 & 0,47 & Medium \\
6 & 0,40 & Medium & 21 & 0,41 & Medium \\
7 & 0,41 & Medium & 22 & 0,42 & Medium \\
8 & 0,52 & Medium & 23 & 0,42 & Medium \\
9 & 0,47 & Medium & 24 & 0,45 & Medium \\
10 & 0,43 & Medium & 25 & 0,39 & Medium \\
11 & 0,41 & Medium & 26 & 0,40 & Medium \\
12 & 0,47 & Medium & 27 & 0,43 & Medium \\
13 & 0,35 & Medium & 28 & 0,36 & Medium \\
14 & 0,38 & Medium & 29 & 0,42 & Medium \\
15 & 0,31 & Medium & & & \\
\hline
\end{tabular}

The results presented in Table 4 reveal that the TTSEDT items difficulty index is in the medium category. It can be noted in the question bank and can then be used to identify student's conception of static electricity. The difficulty index of all the TTSEDT items is within the range of $0.25-0.75$, so the test can be said well (Kanli: 2015). The level of difficulty serves to determine whether the research instrument used is too difficult or easy for students to measure conceptual knowledge, so the test results can actually show the misconceptions shown by the student. The difficulty level of the item will show how many students as a test participant are able to answer the problem correctly from the given problem.

\subsection{Reliability Index}

By using KR-20 it was found that the TTSEDT reliability index was 0.73 . This similar results were obtained by Pesman \& Eryilmaz (2010) on the development of the three-tier test for simple electric circuit that is 0.69; Cetin, Dindar, \& Geban (2011) that found $\mathrm{r}=0.72$ for three-tier diagnostic test to assess high school students' understanding of acids and bases; and Oberoi (2017) that found $r=0.79$ on three-tier concept achievement test in science. This indicates that TTSEDT is a reliable test for measuring student conceptions. Reliability test is one of the criteria of assessment instruments required other than validity. The test is said to have high reliability if it provides consistent results for repeated measurements. Thus, TTSEDT will give the same results for repeated measurements of students' conception of static electricity.

\subsection{Students' conceptions of static electricity}

TSEDT is effectively used to identify the type of students' conception of static electricity Based on the students' response to each tier, it can be determined the percentage of students whose knowledge is classified into scientific concepts, lucky guess, misconception, and lack of knowledge as presented in table 6 . 
Table 6

Recapitulation of student knowledge variety

\begin{tabular}{lc}
\hline Type of students' conception & Percentage of Students \\
\hline Scientific Concept & $44,22 \%$ \\
Lucky Guess & $5,14 \%$ \\
Misconception & $36.92 \%$ \\
Lack of Knowledge & $11,08 \%$ \\
\hline
\end{tabular}

From table 5 it appears that out of 102 students $44.22 \%$ of students whose conception of static electricity is a scientific concept, $5.14 \%$ are the lucky guess (no have conception), 36.92\% of students are misconceptions, and 11, $08 \%$ have lack of knowledge. These results indicate that TTSEDT is effective for identifying students' conceptions of static electricity. Some research on physics material that is also effective for identifying student conceptions is Caleon \& Subramaniam (2010] on dynamic electricity; Taslidere (2016)] on dynamic electricity; at hydrostatic pressures; Turker (2005)] in nature of waves and wave propagation; and Turgut, Gurbuz, \& Turgut (2011) in Electric Current.

\section{Conclusion}

The developed three-tier static electricity diagnostic test is a valid and reliable instrument to identify 12-grade high school students' conceptions about static electricity. Test items are consistent with the entire item, can distinguish high and low ability students, and have a moderate level of difficulty. By using this three tier static electricity diagnostic test, students' conceptions can be categorized into scientific concepts, lucky guesses, misconception, and lack of knowledge. Three-tier static electricity diagnostic test is easy and quick to assess students' conceptions of electricity. It is suggested to physics teachers to use this test to diagnose students' conceptions of static electricity. The results can provide direction for improvements to be made.

Conflict of interest statement and funding sources

We declare that there is no competing interest in the release of this article. This study was funded by the Directorate Research and Community Service, Ministry of Research, Technology, and Higher Education of the Republic of Indonesia.

Statement of authorship

The authors have responsible for the conception and design of the study. The authors have approved the final article.

\section{Acknowledgments}

Thank you to the Director of the Directorate of Research and Community Service of the Ministry of Research, Technology and Higher Education for funding support for this research. Thanks are also given to the Head of SMA Negeri 1 Kediri for the permission given to use 12-grade students as the research subject.

Suantari, N. M. D. P., Suma, K., \& Pujani, N. M. (2018). Development of three tier static electricity diagnostic test to identify student conceptions about static electricity. International Research Journal of Engineering, IT \& Scientific Research, 4(5), 7-16. https://doi.org/10.21744/irjeis.v4n5.285 


\section{References}

Alwan, A. A. (2011). Misconception of heat and temperature among physics students. Procedia-Social and Behavioral Sciences, 12, 600-614.

Arikunto, S., \& Jabar, C. S. A. (2009). Evaluasi program pendidikan: pedoman teoritis praktis bagi mahasiswa dan praktisi pendidikan. Jakarta: Bumi Aksara.

Arslan, H. O., Cigdemoglu, C., \& Moseley, C. (2012). A three-tier diagnostic test to assess pre-service teachers' misconceptions about global warming, greenhouse effect, ozone layer depletion, and acid rain. International journal of science education, 34(11), 1667-1686.

Bardar, E. M., Prather, E. E., Brecher, K., \& Slater, T. F. (2007). Development and validation of the light and spectroscopy concept inventory. Astronomy Education Review, 5(2), 103-113.

Bell, B. F. (1993). Children's science, constructivism and learning in science. Deakin University.

Bento, A. C. (2018). Internet of Things: An Experiment with Residential Automation for Robotics Classes. International Research Journal of Management, IT and Social Sciences (IRJMIS), 5(2), 113-119.

Bilal, E., \& Erol, M. (2009). Investigating students' conceptions of some electricity concepts. Latin-American Journal of Physics Education, 3(2), 1.

Brown, David E., and John Clement. "Overcoming misconceptions via analogical reasoning: Abstract transfer versus explanatory model construction." Instructional science 18, no. 4 (1989): 237-261.

Caleon, I. S., \& Subramaniam, R. (2008). Attitudes towards science of intellectually gifted and mainstream upper primary students in Singapore. Journal of Research in Science Teaching: The Official Journal of the National Association for Research in Science Teaching, 45(8), 940-954.

Caleon, I., \& Subramaniam, R. (2010). Development and application of a three-tier diagnostic test to assess secondary students' understanding of waves. International journal of science education, 32(7), 939-961.

Cataloglu, E., \& Robinett, R. W. (2002). Testing the development of student conceptual and visualization understanding in quantum mechanics through the undergraduate career. American Journal of Physics, 70(3), 238251.

Cetin-Dindar, A., \& Geban, O. (2011). Development of a three-tier test to assess high school students' understanding of acids and bases. Procedia-Social and Behavioral Sciences, 15, 600-604.

Chandrasegaran, A. L., Treagust, D. F., \& Mocerino, M. (2007). The development of a two-tier multiple-choice diagnostic instrument for evaluating secondary school students' ability to describe and explain chemical reactions using multiple levels of representation. Chemistry Education Research and Practice, 8(3), 293-307.

Chang, C. Y., Yeh, T. K., \& Barufaldi, J. P. (2010). The positive and negative effects of science concept tests on student conceptual understanding. International Journal of Science Education, 32(2), 265-282.

Colin, P., Chauvet, F. O., \& Viennot, L. (2002). Reading images in optics: students' difficulties and teachers' views. International Journal of Science Education, 24(3), 313-332.

Cosgrove, M. (1985). A teaching sequence on electric current. Learning in Science: The Implication of Children's Science, 112-123.

Daud, N. S. N., Karim, M. M. A., Hasan, S. W. N. W., \& Rahman, H. A. (2015). Misconception and Difficulties in Introductory Physics Among High School and University Students: An Overview in Mechanics. EDUCATUM Journal of Science, Mathematics and Technology, 2(1), 34-47.

Engelhardt, P. V., \& Beichner, R. J. (2004). Students' understanding of direct current resistive electrical circuits. American Journal of Physics, 72(1), 98-115.

Eshach, H. (2003). Small-group interview-based discussions about diffused shadow. Journal of Science Education and Technology, 12(3), 261-275.

Gonen, S., \& Kocakaya, S. (2010). A Physics Lesson Designed According to 7E Model with the Help of Instructional Technology (Lesson Plan). Turkish Online Journal of Distance Education, 11(1), 98-113.

Gurel, D. K., Eryılmaz, A., \& McDermott, L. C. (2015). A Review and Comparison of Diagnostic Instruments to Identify Students' Misconceptions in Science. Eurasia Journal of Mathematics, Science \& Technology Education, 11(5).

Kaltakçi, D., \& Didiş, N. (2007, April). Identification of Pre-Service Physics Teachers' Misconceptions on Gravity Concept: A Study with a 3-Tier Misconception Test. In AIP Conference Proceedings (Vol. 899, No. 1, pp. 499500). AIP.

Kanli, U. (2015). Using a Two-Tier Test to Analyse Students' and Teachers' Alternative Concepts in Astronomy. Science Education International, 26(2), 148-165. 
Kılıç, D., \& Sağlam, N. (2009). Development of a Two-Tier Diagnostic Test to Determine Students' Understanding of Concepts in Genetics. Eurasian Journal of Educational Research (EJER), (36).

Koudelkova, V., \& Dvorak, L. (2015, May). High school students' misconceptions in electricity and magnetism and some experiments that can help students to reduce them. In Nuovo Cimento C-Colloquia And Communications In Physics (Vol. 38, No. 3). VIA Saragozza, 12, I-40123 Bologna, Italy: Soc Italiana Fisica.

Kutluay, Y. (2005). Diagnosis of eleventh grade students' misconceptions about geometric optic by a three-tier test. Unpublished master thesis, Middle East Technical University, Ankara.

Libarkin, J. (2008, October). Concept inventories in higher education science. In BOSE Conf.

Maloney, D. P., O’Kuma, T. L., Hieggelke, C. J., \& Van Heuvelen, A. (2001). Surveying students' conceptual knowledge of electricity and magnetism. American Journal of Physics, 69(S1), S12-S23.

Martin-Blas, T., Seidel, L., \& Serrano-Fernández, A. (2010). Enhancing Force Concept Inventory diagnostics to identify dominant misconceptions in first-year engineering physics. European Journal of Engineering Education, 35(6), 597-606.

Oberoi, M. B. (2017). Construction and Standardization of Three Tier Concept Achievement Test CAT in Science. International Journal of Engineering Science, 5634.

Önder, İ. (2017). The Effect of Conceptual Change Texts Supplemented Instruction on Students' Achievement in Electrochemistry. International Online Journal of Educational Sciences, 9(4).

Osborne, R. J., \& Gilbert, J. K. (1979). Investigating student understanding of basic physics concepts using an interview-about-instances technique. Research in Science Education, 9(1), 85-93.

Osborne, R. J., \& Gilbert, J. K. (1980). A technique for exploring students' views of the world. Physics Education, 15(6), 376.

Ozkan, G., \& Selçuk, G. S. (2012). How effective is “conceptual change approach" in teaching physics. Journal of Educational and Instructional Studies in the World, 2(2), 46-63.

Pacala, S. W., \& Deutschman, D. H. (1995). Details that matter: the spatial distribution of individual trees maintains forest ecosystem function. Oikos, 357-365.

Peşman, H., \& Eryılmaz, A. (2010). Development of a three-tier test to assess misconceptions about simple electric circuits. The Journal of educational research, 103(3), 208-222.

Petersson, G. (2002, June). Description of cognitive development from a constructivist perspective. In third European Symposium on Conceptual Change.

Sencar, S., \& Eryilmaz, A. (2004). Factors mediating the effect of gender on ninth-grade Turkish students' misconceptions concerning electric circuits. Journal of Research in Science Teaching: The Official Journal of the National Association for Research in Science Teaching, 41(6), 603-616.

Taslidere, E. (2016). Development and use of a three-tier diagnostic test to assess high school students' misconceptions about the photoelectric effect. Research in Science \& Technological Education, 34(2), $164-186$.

Thiagarajan, S. (1974). Instructional development for training teachers of exceptional children: A sourcebook.

Treagust, D. F. (1988). Development and use of diagnostic tests to evaluate students' misconceptions in science. International journal of science education, 10(2), 159-169.

Turgut, Ü., Gürbüz, F., \& Turgut, G. (2011). An investigation 10th grade students' misconceptions about electric current. Procedia-Social and Behavioral Sciences, 15, 1965-1971.

Türker, F. (2005). Developing a three-tier test to assess high school students' misconceptions concerning force and motion. Unpublished master" s thesis, Middle East Technical University, Ankara, Turkey.

Wijaya, C. P., \& Muhardjito, M. (2016). The diagnosis of senior high school class x mia b students misconceptions about hydrostatic pressure concept using three-tier. Jurnal Pendidikan IPA Indonesia, 5(1), 13-21.

Suantari, N. M. D. P., Suma, K., \& Pujani, N. M. (2018). Development of three tier static electricity diagnostic test to identify student conceptions about static electricity. International Research Journal of Engineering, IT \& Scientific Research, 4(5), 7-16. https://doi.org/10.21744/irjeis.v4n5.285 


\section{Biography of Authors}

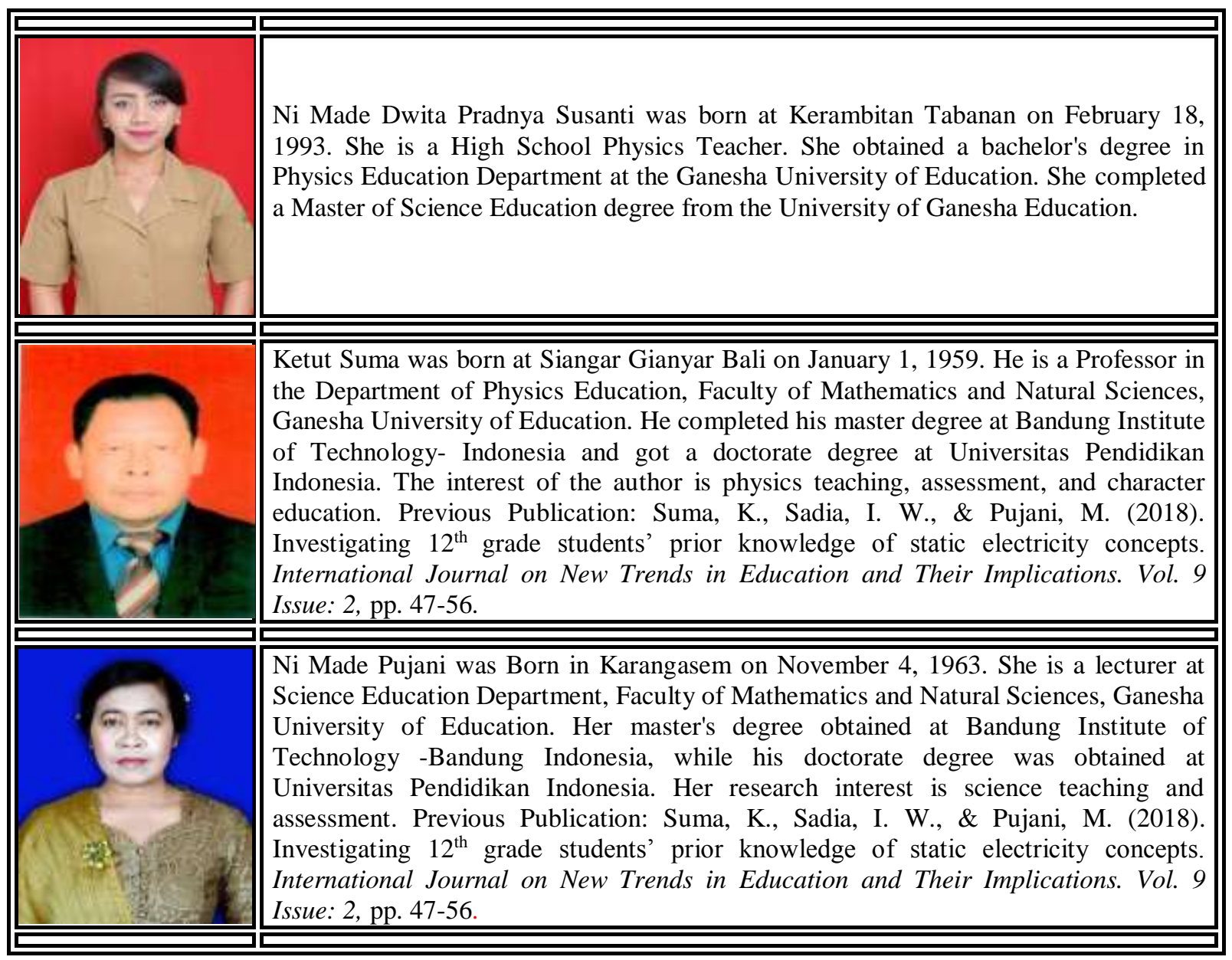

